
\title{
$\begin{array}{ll}\text { Research Square } & \begin{array}{l}\text { Preprints are preliminary reports that have not undergone peer review. } \\ \text { They should not be considered conclusive, used to inform clinical practice, } \\ \text { or referenced by the media as validated information. }\end{array}\end{array}$
}

\section{Female Homicides and Femicides in Ecuador: A Nationwide Ecological Analysis From 2001-2017}

\section{Esteban Ortiz-Prado ( $\nabla$ e.ortizprado@gmail.com )}

Universidad de Las Americas

\section{Paola Villagran}

Universidad de Las Americas

\section{Ana M Abarca}

Universidad de Las Americas

\section{Aquiles R Henriquez}

Universidad de Las Americas

Katherine Simbaña-Rivera

Universidad de Las Americas

\section{Lenin Gómez-Barreno}

Universidad de Las Americas

Ana M. Diaz

Universidad de Las Americas

\section{Carla E Moyano}

Universidad de Las Americas

\section{Vanessa Arcos-Valle}

Universidad de Las Americas

\section{Maria Dolores Miño}

Director of the Observatory of Human Rights and Justice, Quito, Ecuador

\section{Sara Morgan}

University of Southampton

\section{Research Article}

Keywords: femicide, crime, gender-based violence, violence, gender, homicide

Posted Date: August 30th, 2021

DOI: https://doi.org/10.21203/rs.3.rs-758183/v1

License: (c) (i) This work is licensed under a Creative Commons Attribution 4.0 International License. Read Full License 


\section{Abstract}

Background: Gender-based violence is a major public health concern arising from the structural discrimination of women and girls. In 2014, Ecuador criminalized acts of femicide in response to a growing crisis across the region. As no epidemiological studies on the state of female homicides have been published, we estimated trends occurring between 2001 and 2017.

Methods: Using data from the National Institute of Census and Statistics we estimated the annual mortality rates, cumulative incidence and incidence risks differences for female homicides, from 2001 - 2017. The impact of aggressions, assaults and violence on years of life lost due to premature mortality was estimated using the Human Capital method.

Results: Over the period, at least 3,236 cases of female homicides were reported. The highest murder rate occurred in the province of Sucumbíos (6.5 per 100,000) and in the Putumayo canton (12.5 per 100,000). The most common way to murder their victims was using firearms (38\%). The highest incidence risk was estimated for women aged between 25-29, at 4.5 (3.9 - 5.1), of primary school attainment at 17.2 (14.6-20.3) and of Afro-Ecuadoran descent $18 \cdot 1$ (10.5-30.9). Femicide-related costs reached, on average, $\$ 35$ million per year and more than $\$ 500$ million lost from 2001 to 2017.

Conclusions: The high rates, distribution and cost indicate that investments are urgently needed to address the structural causes and reduce the impact of femicides in Ecuador; thereby protecting the livelihood and well-being of their women and girls.

\section{Introduction}

Gender-based violence is a major public health concern and violation of women's human rights that affects communities all over the world (1). An estimated 1.2 billion women $-30 \%$ of the female population - have experienced either physical and/or sexual intimate partner violence or non-partner sexual violence in their lifetime (2). When such violence results in an assassination, or femicide, societies experience the most extreme form of violence against women (3). Several human rights bodies have characterized femicides as a particular type of crime, that occurs in the 'context of structural discrimination against women and girls.'(4) Femicides are therefore not isolated occurrences; they result from systematic and structural phenomenon, enrooted in social behaviours and accepted stereotypes. $(5,6)$. Studies attribute several risk and protective factors to the risk of a femicide occurring. These include intra-familial relationships, intimate partner violence, alcohol or drugs consumption, level of education, poverty, religious beliefs and other cultural aspects, that vary from region to region $(5,7-12)$.

Global estimates suggest that at least 87,000 women were assassinated in 2017 , representing more than six women killed every hour (3). The African continent has the highest standardised murder rate with 1.6 per 100,000 cases, followed by the Americas with $1 \cdot 3$ per 100,000 and Oceania with $1 \cdot 3$ per 100,000 (3). Empirical evidence on the global demographics and epidemiological distribution still remain rare (2). In Latin America, a region with high levels of civil violence, very few countries have reported the overall impact of violence towards women at a national level (13-16). In 2014, Ecuador criminalised femicide through the inclusion of Article 141 of the Organic Criminal Code (OCC). As one of the last countries in the region to provide such protection to women and girls, this was an important milestone and the result of intense lobbying and activism by women's rights advocates and organizations. The legislation for femicide has become intimately linked with acts of gender-based violence in 
Ecuador and (17) states that "the person who, as a result of power relations manifested in any type of violence, kills a woman due to the fact that she is or because of her gender, they will be punished with imprisonment from 22 to 26 years". (18)

In Ecuador, although sociological manuscripts, legal interpretations and other historical evidence are available, an epidemiological study of the prevalence of femicide has never been attempted. This study aims to address the gap in the literature on crimes against women, specifically female homicides and femicides, occurring in Ecuador from 2001-2017; thereby creating further awareness on a stark reality that, until now, has been poorly analysed within the national context. Specifically, we aim to examine the social, economic, geographical and demographic patterns of femicides nationally and the burden of femicides through years of life lost and economic cost.

\section{Methods}

\section{Data Source}

We extracted mortality data from the National Institute of Census and Statistics (INEC) of Ecuador, which is responsible for generating and reporting the official national statistics for decision making in public policy. The country is divided into four geographical regions: the coastal region; the highlands or sierra region; the amazon region and; the insular region (Galapagos Islands). The extracted data included available information (2001-2017) from the 24 provinces and the 223 cantons in the country, where cantons are political subdivision of a province in the country. In 2017 the population of Ecuador was estimated at 16,624,424 inhabitants based on the latest available census data from 2010 and its projections (19). The dataset contains information on age, civil status, educational status, ethnicity, date of death, gender, place of registration (urban or rural) and the underlying cause of death coded using the International Classification of Diseases, tenth revision (ICD-10). To validate the data, comparisons were made against the official records held by the national police to ensure accuracy in reporting through the INEC database. The dataset is readily available as comma-separated values (CSV) or dBase database file (DBF) format in the public INEC's domain: https://aplicaciones3.ecuadorencifras.gob.ec/sbi-war/

\section{Data Analysis}

Using the ICD-10 classifications (see Appendix), we estimated the annual mortality rate for female homicides per 100,000 population. These were age-standardized using projection data by canton and province according to the available information from the INEC Census in 2010 (19). Mortality rate was calculated by dividing the number of new cases per year, by the total population at risk during each year. We calculated the incidence risk for female homicides per 100,000 population and $95 \% \mathrm{Cl}$ by 5-year age group (5-9, 10-14, 15-19, 20-24, 25-29... 65 years and older) compared to the youngest age group (0-4 years) and to male homicides within the same period. Analysis of incidence risk of female homicides by social, economic and demographic variables was calculated using ethnicity (indigenous, afro-ecuadorian/ afro-descendant, montubia, mixed, white, other) highest educational attainment achieved (primary school, secondary school (incomplete), high school, postgraduate) and civil status (united by law, single, married, divorced, separated, widowed). Trends by region and province were estimated using cumulative incidence across the years 2001 - 2017. Cumulative incidence was estimated by dividing the number of cases with the population at risk (gender and age per year) and then producing a final average estimate. 
The ICD-10 codes for assault and aggression (see Appendix) were categorized into nine groups representing underlying cause of death by: chemicals, strangulation, drowning, sexual aggressions, firearms, fire-related mechanisms, sharp objects (e.g. knife), blunt objects and other. Comparison of cause of female deaths against cause of male deaths were made using these codes. All statistical analysis accepted significance with a p-value $<0.05$. Calculations were completed using IBM SPSS Statistics for Windows, Version $24 \cdot 0$ and R Core Team software 2018 version 3·5·1. Cartography was generated using QGIS Development Team, version 2·8.

\section{Burden of femicides}

To analyse the impact of femicides we calculated the overall impact of aggressions, assaults and violence on years of life lost due to premature mortality (YLL). YLL were calculated as the number of deaths multiplied by life expectancy of the woman at the age of death, considering a life expectancy at birth of $86 \cdot 2$ years according to the Global Burden of Disease. This methodology has been described by Murray and colleagues and previously used in similar analysis; no time discount, nor age weighting were added to the calculations (20). Indirect costs were calculated using the human-capital $(\mathrm{HC})$ method to value productivity losses. The $\mathrm{HC}$ method considers the person's hours of productivity that are lost until their retirement age. Since it was not possible to ascertain the level of income of each of the deceased women, we based our estimates at the official basic salary for women of productive age at the time of their death. The official minimum wage, which varies accordingly to the GDP per capita, ranges from $\$ 370$ to $\$ 390$ USD per month. To estimate the total productivity losses, we multiplied the number of YLL in woman aged 15 to 64 years old by the official GDP per capita at the age of death.

\section{Results}

We analysed data from 17 years of available data (2001-2017), which included 3,236 cases of female homicides. Since 2014, where femicide began to be classified as such, 249 cases of femicide have been registered, increasing from $18 \%$ in 2014 to $57 \%$ in 2017 . The annual homicide rate per 100,000 varied from $1 \cdot 8 / 100,000$ to $3 \cdot 8 / 100,000$ (Figure 1).

The majority of deaths occurred among young women between 20 and 30 years old, representing more than $28 \%$ of the total number of violent deaths amongst women. The mean age of women in the overall period was 33 . The youngest victims were observed in the group of sexual related assaults (10 years median $95 \% \mathrm{Cl}, 6-16)$ and the oldest victims were killed by blunt objects (33 years median $95 \% \mathrm{Cl}, 28-44$ ). The youngest victim reported was 1year-old and the oldest 99 years.

Female homicides were most prevalent in urban areas $(84 \%-N=2,718)$ compared to rural areas. The region with the highest cumulative incidence rate 100,000 people was the amazon region $(48 \cdot 1 / 100,000)$, followed by the coast $(43 \cdot 2 / 100,000)$, the highlands $(31 \cdot 3 / 100,000)$ and the Galapagos islands, where no murders against women have been reported. Of the 24 provinces, the highest rate was Sucumbíos (6·5/100,000), Esmeraldas $(4 \cdot 6 / 100,000)$, Santo Domingo de los Tsachilas (4·3/100,000), Bolivar (3·8/100,000), and El Oro $(3 \cdot 6 / 100,000)$ (Figure 2).

Of the 223 cantons, the top five most violent in terms of the overall (2001-2017) homicide rate per 100,000 were Putumayo (12·5/100,000), San Lorenzo (11·1/100,000), Palestina (10.5/100,000), Las Lajas $(9 \cdot 9 / 100,000)$ and Lago Agrio $(9 \cdot 3 / 100,000)$ (Figure 3$)$. In the overall 17 years of data, 32 cantons did not report any homicide or femicide. 
Compared to the youngest group, women from 25 to 29 years old had the highest incidence risk at 7.0 (95\% Cl 5.6 - 8.8). Compared to males, females had a lower incidence risk of homicide at each age category, although this difference was less apparent amongst younger age groups.

Table 1 Incidence risk of female homicide in Ecuador by age category, 2001 - 2017

\begin{tabular}{|c|c|c|c|c|c|}
\hline $\begin{array}{l}\text { Age } \\
\text { group }\end{array}$ & Population & $\begin{array}{l}\text { Cases } \\
(\mathrm{n})\end{array}$ & $\begin{array}{l}\text { Rate per } \\
100,000 \\
\text { population [Cl] }\end{array}$ & $\begin{array}{l}\text { Incidence risk } \\
\text { compared to lowest } \\
\text { age group [Cl] }\end{array}$ & $\begin{array}{l}\text { Incidence risk compared to } \\
\text { male homicides at same age } \\
\text { group [CI] }\end{array}$ \\
\hline $0-4$ & 826,528 & 89 & $\begin{array}{l}0 \cdot 68[0 \cdot 48- \\
0 \cdot 88]\end{array}$ & Ref. & $0.79[0.58-1 \cdot 09]$ \\
\hline $5-9$ & 799,393 & 92 & $\begin{array}{l}0.73[0.47- \\
1.00]\end{array}$ & $1.07[0.79-1.43]$ & $0 \cdot 84[0.61-1 \cdot 14]$ \\
\hline $\begin{array}{l}10- \\
14\end{array}$ & 759,419 & 106 & $\begin{array}{l}0.90[0 \cdot 60- \\
1 \cdot 15]\end{array}$ & $1 \cdot 30[0.97-1.71]$ & $0.54[0.41-0.71]^{\star}$ \\
\hline 15-19 & 708,354 & 331 & $\begin{array}{l}2 \cdot 56[2 \cdot 08- \\
3 \cdot 03]\end{array}$ & $4.34[3.43-5 \cdot 48]^{\star}$ & $0 \cdot 14[0 \cdot 12-1 \cdot 16]^{\star}$ \\
\hline $20-24$ & 656,390 & 450 & $\begin{array}{l}4 \cdot 14[3 \cdot 68- \\
4 \cdot 61]\end{array}$ & $6.36[5.06-7.98]^{\star}$ & $0.09[0.08-0.11]^{\star}$ \\
\hline $25-29$ & 612,107 & 463 & $\begin{array}{l}4 \cdot 47[3 \cdot 86- \\
5 \cdot 08]\end{array}$ & $7 \cdot 02[5.59-8 \cdot 80]^{\star}$ & $0.09[0.08-0.11]^{\star}$ \\
\hline $30-34$ & 562,150 & 342 & $\begin{array}{l}3 \cdot 50[2 \cdot 93- \\
4 \cdot 07]\end{array}$ & $5 \cdot 65[4 \cdot 47-7 \cdot 13]^{\star}$ & $0.07[0.06-0.08]^{\star}$ \\
\hline $35-39$ & 501,112 & 290 & $\begin{array}{l}3 \cdot 47[2 \cdot 91- \\
4 \cdot 02]\end{array}$ & $5 \cdot 37[4 \cdot 23-6 \cdot 81]^{\star}$ & $0.09[0.08-0.12]^{\star}$ \\
\hline $40-44$ & 442,537 & 260 & $\begin{array}{l}3 \cdot 48[2 \cdot 93- \\
4 \cdot 04]\end{array}$ & $5 \cdot 45[4 \cdot 28-6 \cdot 93]^{\star}$ & $0.12[0.08-0 \cdot 11]^{\star}$ \\
\hline $45-49$ & 386,889 & 199 & $\begin{array}{l}3 \cdot 28[2 \cdot 60 \\
-3 \cdot 97]\end{array}$ & $4 \cdot 78[3 \cdot 71-6 \cdot 13]^{\star}$ & $0.90[0.08-0.11]^{\star}$ \\
\hline $50-54$ & 326,634 & 149 & $\begin{array}{l}2 \cdot 70[2 \cdot 10- \\
3 \cdot 29]\end{array}$ & $4 \cdot 23[3 \cdot 25-5 \cdot 50]^{\star}$ & $0.11[0.08-0.12]^{\star}$ \\
\hline $55-59$ & 266,079 & 93 & $\begin{array}{l}1 \cdot 92[1 \cdot 44- \\
2 \cdot 40]\end{array}$ & $3 \cdot 24[2 \cdot 42-4 \cdot 33]^{\star}$ & $0.09[0.07-0.12]^{\star}$ \\
\hline $60-64$ & 212,730 & 85 & $\begin{array}{l}2 \cdot 34[1 \cdot 69- \\
2 \cdot 98]\end{array}$ & $3.71[2.75-4.99]^{\star}$ & $0.13[0.11-0.17]^{\star}$ \\
\hline$>65$ & 508,031 & 286 & $\begin{array}{l}2 \cdot 57[2.09- \\
3.05]\end{array}$ & $4 \cdot 10[3 \cdot 01-5 \cdot 58]^{\star}$ & $0 \cdot 16[0 \cdot 12-0 \cdot 21]^{\star}$ \\
\hline Total & $7,568,353$ & 3,235 & $\mathrm{~N} / \mathrm{A}$ & N/A & N/A \\
\hline \multicolumn{6}{|c|}{${ }^{*}$-value ${ }^{* \star *}<0.05 ; * *<0.01 ; *<0.001$} \\
\hline
\end{tabular}


Table 2: Incidence risk of femicide in Ecuador with social, economic and demographic variables

Cases, $\mathrm{n}(\%) \quad$ Incidence risk [Cl 95\%]

\begin{tabular}{lll}
\hline Civil status & & \\
\hline United by law ${ }^{i}$ & $573(18)$ & $0.66[0.60-0.73]$ \\
\hline Single & $1,419(44 \cdot 0)$ & Ref. \\
\hline Married & $850(26 \cdot 0)$ & $0.62[0.56-0.67]$ \\
\hline Divorced & $105(3.0)$ & $1.05[0.86-1 \cdot 28]$ \\
\hline Separated & $27(1 \cdot 0)$ & $0.10[0.07-0.15]$ \\
\hline Widowed & $263(8.0)$ & $1.08[0.95-1 \cdot 23]$ \\
\hline
\end{tabular}

\section{Highest level of educational attainment}

\begin{tabular}{|c|c|c|}
\hline None & $276(8 \cdot 5)$ & $0.82[0.67-0.99]$ \\
\hline Primary school & $1,102(34 \cdot 1)$ & $17 \cdot 2[14 \cdot 6-20 \cdot 3]$ \\
\hline Incomplete secondary school & $866(26 \cdot 7)$ & $0 \cdot 25[0 \cdot 21-0 \cdot 30]$ \\
\hline Complete High school & $105(3 \cdot 3)$ & $0.08[0.07-0.11]$ \\
\hline Postgraduate & $161(5 \cdot 0)$ & Ref. \\
\hline No information & $726(22 \cdot 4)$ & $4 \cdot 49[3 \cdot 78-5 \cdot 33]$ \\
\hline \multicolumn{3}{|l|}{ Ethnicity } \\
\hline Indigenous & $75(2 \cdot 3)$ & $4 \cdot 64[2 \cdot 62-8 \cdot 21]$ \\
\hline Afro-Ecuadorian / Afro-descendant & $290(8 \cdot 9)$ & $18 \cdot 1[10 \cdot 5-30 \cdot 9]$ \\
\hline Montubia & $9(0 \cdot 3)$ & $0 \cdot 58[0 \cdot 24-1 \cdot 33]$ \\
\hline Mixed & $979(30 \cdot 3)$ & $5.91[3.49-10 \cdot 0]$ \\
\hline White & $14(0 \cdot 4)$ & Ref. \\
\hline Other & $4(0 \cdot 1)$ & $5 \cdot 25[1 \cdot 72-15 \cdot 96]$ \\
\hline No information & $1,865(57 \cdot 6)$ & $\mathrm{N} / \mathrm{A}$ \\
\hline
\end{tabular}

Notes: ${ }^{i}$ Ecuador being married entitles all the civil rights, whereas united by law is a legal status acquired after the couple have spent two years living together and on signing a free union form.

The most common cause of death were firearms (38\%), followed by sharps objects (30\%) and strangulation (14\%) (Table 3). Compared to males, females had a 4.33 incidence risk ( $95 \% \mathrm{Cl} 1.63-11.4)$ of death due to sexual aggressions.

\section{Table 3: Cause of death}




\begin{tabular}{lllll} 
& Cases & Age & Age & Incidence risk compared to males [CI 95\%] \\
& $(\mathrm{n})$ & $\begin{array}{l}\text { Mean } \\
\text { [95\% Cl] }\end{array}$ & $\begin{array}{l}\text { Median } \\
{[95 \% \mathrm{Cl}]}\end{array}$ & \\
\hline Chemicals & $46(1)$ & $25[19-32]$ & $22[19-32]$ & $0 \cdot 10[0 \cdot 06-0 \cdot 17]$ \\
\hline Strangulation & $444(14)$ & $36[34-39]$ & $28[26-32]$ & $0 \cdot 42[0 \cdot 37-0 \cdot 46]$ \\
\hline Drowning & $16(0)$ & $38[29-46]$ & $26[22-42]$ & $0 \cdot 06[0 \cdot 03-0 \cdot 10]$ \\
\hline Sexual Aggressions & $22(1)$ & $25[9-40]$ & $10[6-16]$ & $4 \cdot 33[1 \cdot 63-11 \cdot 4]$ \\
\hline Firearms & $1,222(38)$ & $33[32-34]$ & $30[29-32]$ & $0 \cdot 06[0 \cdot 06-0 \cdot 06]$ \\
\hline Fire related & $18(1)$ & $34[19-49]$ & $30[17-45]$ & $0 \cdot 36[0 \cdot 21-0 \cdot 62]$ \\
\hline Sharp Objects & $960(30)$ & $36[35-37]$ & $32[31-34]$ & $0 \cdot 15[0 \cdot 14-0 \cdot 16]$ \\
\hline Blunt Object & $83(3)$ & $39[33-45]$ & $33[28-44]$ & $0 \cdot 17[0 \cdot 13-0 \cdot 21]$ \\
\hline Others & $425(13)$ & $37[34-39]$ & $31[29-34]$ & $0 \cdot 27[0 \cdot 24-0 \cdot 29]$ \\
\hline Total & 3,263 & 33.6 & 26.8 & N/A
\end{tabular}

In most cases of femicides in Ecuador, women were young. The vast majority of women killed were under 35 years of age (57.9\%), so the economic burden due to lost lives is significant, reaching an average of 9,675 years of life lost prematurely per year, and more than 164,000 years in the last 17 years of available data. Femicide-related costs attributed to femicide reached, on average, \$35 million per year and more than \$500 million lost from 2001 to 2017 (Table 4).

Table 4: Years of life lost (YLL) due to female homicide in Ecuador, 2001 and 2017. 


\begin{tabular}{llll} 
Year & Cases/year & YLL* & Economic Losses (US\$) ** \\
\hline $\mathbf{2 0 1 7}$ & 177 & 9,025 & $50,143,307$ \\
\hline $\mathbf{2 0 1 6}$ & 179 & 9,242 & $47,448,887$ \\
\hline $\mathbf{2 0 1 5}$ & 162 & 8,076 & $39,547,989$ \\
\hline $\mathbf{2 0 1 4}$ & 151 & 7,457 & $41,455,658$ \\
\hline $\mathbf{2 0 1 3}$ & 159 & 7,751 & $40,789,337$ \\
\hline $\mathbf{2 0 1 2}$ & 201 & 9,956 & $49,850,610$ \\
\hline $\mathbf{2 0 1 1}$ & 226 & 11,222 & $53,612,987$ \\
\hline $\mathbf{2 0 1 0}$ & 189 & 9,715 & $40,401,612$ \\
\hline $\mathbf{2 0 0 9}$ & 194 & 10,262 & $36,924,730$ \\
\hline $\mathbf{2 0 0 8}$ & 200 & 10,256 & $36,835,534$ \\
\hline $\mathbf{2 0 0 7}$ & 231 & 11,611 & $32,948,806$ \\
\hline $\mathbf{2 0 0 6}$ & 219 & 11,501 & $29,601,214$ \\
\hline $\mathbf{2 0 0 5}$ & 189 & 10,045 & $25,545,668$ \\
\hline $\mathbf{2 0 0 4}$ & 211 & 10,717 & $21,319,347$ \\
\hline $\mathbf{2 0 0 3}$ & 170 & 8,416 & $16,741,380$ \\
\hline $\mathbf{2 0 0 2}$ & 201 & 10,387 & $18,178,711$ \\
\hline $\mathbf{2 0 0 1}$ & $\mathbf{1 7 7}$ & 8,840 & $13,903,903$ \\
\hline Total & $\mathbf{3}, \mathbf{2 3 6}$ & $\mathbf{1 6 4 , 4 7 9}$ & $\mathbf{5 9 5 , 2 4 9 , 6 8 0}$ \\
\hline * Based on Life Expectancy according to GBD2010, ** Human Capital Method
\end{tabular}

\section{Discussion}

This is the first report conducted on the state of femicides in Ecuador. Gender-based violence is a leading cause of injury and disability worldwide. When such violence culminates in the death of a girl or woman, this has disastrous long-term consequences on communities and societies. Gender-based violence has a huge social and economic cost in Ecuador, estimated at \$35 million per year, and an average of 9,675 years of life lost prematurely per year.

Consistent with other studies, females under the age of 35 were most affected, whilst lower education conferred a greater disadvantage. Although an explanation on the exact mechanism through which lower education influences the likelihood of gender-based violence could not be offered here, other studies suggest that poor access to, and participation in, education promote gender inequalities and female disempowerment (21).

In 2011, The National Survey on family relations and gender violence against women reported that six out of ten women experienced gender-based violence, with those of Indigenous and Afro-Ecuadorian descent being most afflicted. This is consistent with the evidence presented here, which shows that the highest prevalence of femicides occurred amongst Afro-Ecuadorian women. In contrast to the National Survey report, that found the highest rates 
of psychological, sexual and physical violence in Morona Santiago, Tungurahua and Pastaza (22), our study shows higher rates of femicides in the provinces of Sucumbios, Esmeraldas, Santo Domingo de los Tsachilas, Bolivar, and El Oro throughout the period of 2001 to 2017. Although most murders generally occurred in urban areas, a closer analysis at the provincial level showed that a number of cantons of smaller populations and higher rurality (such as those in Pastaza and Esmeraldas) had very high rates of femicide. This could in part be explained by recent reports of civil violence at the Ecuadorian borders; it is also plausible that social norms inherent within the rural context, may provide agency for such acts of violence $(23-25)$.

In terms of policy, The Inter-American Court of Human Rights affirm that States are obliged, under International Law, to adopt effective public policy in order to prevent acts of violence towards women before they result in a femicide (26). It was not until 2014 that such actions were brought into discussion in Ecuador (27). Prior to 2014, there was no criminal procedure to hold perpetrators accountable for attacks of violence and discrimination made against women and girls. One of the limitations of this study was therefore that the classification of femicide could not proceed 2014, when the legislation was put in place, and therefore the information collected from 2001 to 2013 was based on the deaths of women due to homicides.

Another limitation was that some of the social, economic and demographic information reported here were based on reporting from close family members of the deceased and the professionals involved; this may have resulted in mis-classifications or inaccuracies in reporting.

A further limitation was that we lacked information on the perpetrator of the crime, which meant that we could not confirm the rates of intimate partner homicide (27). According to the Ecuadorian State established a Gender Atlas, the most common perpetrators of femicides included people unknown to the victim (30\%), cohabitant ( $30 \%)$, former partner (16\%), family member (8\%), boyfriend (7\%), ex-boyfriend (2\%) among others (28). Further studies should seek to address this data gap.

Overall these findings demonstrate both the scale and impact of female homicides and femicides in Ecuador. Although not analysed here, other studies elsewhere have reported implementation problems following changes in legislation. Domestic violence laws may not be accompanied by the required budget allocations, for example, or certain authorities involved in law enforcement may be resistant (29). A national strategy to tackle femicide, through community initiatives that address the risk factors of violence (such as the acceptability of violence) alongside better enforcement of laws is recommended. For example, group educational training that target inequitable gender norms, and address underlying expectations around female and male behaviour, have been shown to be effective within targeted populations in LMICs. Evidence also shows that community mobilization programmes - complex interventions involving many community stakeholders - can also promote changes in norms, discourse and practice through communication channels such as radio and television.

Femicide is a global human rights violation that until now has received very little attention and research in Ecuador. Policy makers should consider the devastating impact of femicides on the national economy, and fund further investment into the enforcement of new legislation, as well as national and local programmes that address gender inequality; thereby protecting the livelihood and well-being of their women and girls.

\section{Declarations}

\section{Ethical approval and consent to participate}


The research study was a secondary data analysis of publicly available, non-identifiable, anonymized data. Therefore according to local regulations did not require ethical approval.

\section{Role of the funding source}

This work was funded by the Universidad de Las Americas through their annual general research projects funds.

\section{Consent for publication}

Not applicable

\section{Availability of data material}

The datasets can be accessed from: https://aplicaciones3.ecuadorencifras.gob.ec/sbi-war/

\section{Acknowledgements}

The authors would like to thank Rebeca Bravo who edited the maps included in this publication.

\section{Competing interests}

We declare no competing interests.

\section{Authors' Contributions}

EOP contributed towards the conception and design of the whole project, obtained full access to the data from the National Institutes of Statistic in Ecuador, and was primarily accountable for all aspects of work, ensuring integrity and accuracy of the research as well as of the drafting of the manuscript, and the final responsibility for the decision to submit for publication.

PV, KSR and LGB contributed towards the data acquisition, the geographical display of the data and the elaboration of the tables.

ALM and ARH undertook the burden of femicide analysis and the economic impact of femicide in Ecuador.

AMD, CEM and VAV manually retrieved the sociodemographic variables from 2001-2003 and obtained the 20012017 population projections for the mortality rate analysis.

MDM offered legal interpretation on femicides, including the analysis of the legal code and provided input on the legal aspects of the literature and methodology, and critically reviewed the manuscript.

SM critically reviewed and edited the manuscript, providing input towards the reporting of the data, and its interpretation.

All authors have read and approved the manuscript.

\section{References}

1. García-Moreno C, Zimmerman C, Morris-Gehring A, Heise L, Amin A, Abrahams N, et al. Addressing violence against women: a call to action. The Lancet. 2015;385(9978):1685-1695. 
2. Decker MR, Peitzmeier S, Olumide A, Acharya R, Ojengbede O, Covarrubias L, et al. Prevalence and health impact of intimate partner violence and non-partner sexual violence among female adolescents aged 15-19 years in vulnerable urban environments: a multi-country study. J Adolesc Health. 2014;55(6):S58-S67.

3. UNODC. Global Study on Homicide: Gender-related killing of women and girls [Internet]. United Nations Office on Drugs and Crime; 2018. Disponible en: https://www.unodc.org/documents/data-andanalysis/GSH2018/GSH18_Gender-related_killing_of_women_and_girls.pdf

4. McCulloch J, Fitz-Gibbon K, Maher J, Walklate S. United Nations Human Rights Office of the High Commissioner: Call for femicide related data and information. 2018;

5. Prieto-Carrón M, Thomson M, Macdonald M. No more killings! Women respond to femicides in Central America. Gend Dev. 2007;15(1):25-40.

6. Código Orgánico Integral Penal C. Quito. Ecuador: Ministerio de Justicia. Derechos Hum Cultos. 2014;

7. Faqir F. Intrafamily femicide in defence of honour: the case of Jordan. Third World Q. 2001;22(1):65-82.

8. Al Gharaibeh FM. Debating the role of custom, religion and law in 'honour'crimes: implications for social work. Ethics Soc Welf. 2016;10(2):122-139.

9. Reckdenwald A, Yohros A, Szalewski A. Health Care Professionals, Rurality, and Intimate Femicide. Homicide Stud. 2018;22(2):161-187.

10. Johnson H, Eriksson L, Mazerolle P, Wortley R. Intimate femicide: The role of coercive control. Fem Criminol. 2019;14(1):3-23.

11. Sharps PW, Campbell J, Campbell D, Gary F, Webster D. The role of alcohol use in intimate partner femicide. Am J Addict. 2001;10(2):122-135.

12. Frye V, Wilt S. Femicide and social disorganization. Violence Women. 2001;7(3):335-351.

13. Carey Jr D, Torres MG. Precursors to femicide: Guatemalan women in a vortex of violence. Lat Am Res Rev. 2010;45(3):142-164.

14. Martins-Filho PRS, Mendes MLT, Reinheimer DM, do Nascimento-Júnior EM, Vaez AC, Santos VS, et al. Femicide trends in Brazil: relationship between public interest and mortality rates. Arch Womens Ment Health. 2018;21(5):579-582.

15. Albuquerque PH, Vemala PR. A statistical evaluation of femicide rates in Mexican cities along the US-Mexico border. SSRN ELibrary. 2008;

16. Bellino M. Feminicide and Silence in" Postwar" Guatemala. Womens Policy J Harv. 2009;7:5.

17. Yépez M. El Femicidio en el COIP [Internet]. Derecho Ecuador. 2014 [citado 17 de julio de 2019]. Disponible en: https://www.derechoecuador.com/el-femicidio-en-el-coip

18. Asamblea Nacional de la República del Ecuador. Código Orgánico Integral Penal [Internet]. Quito-Ecuador; 2014. Report No.: 180. Disponible en:

https://tbinternet.ohchr.org/Treaties/CEDAW/Shared\%20Documents/ECU/INT_CEDAW_ARL_ECU_18950_S.pdf

19. INEC. Censo de Población y Vivienda. 2010.

20. Ortiz-Prado E, Simbaña K, Gómez L, Henriquez-Trujillo AR, Cornejo-Leon F, Vasconez E, et al. The disease burden of suicide in Ecuador, a 15 years' geodemographic cross-sectional study (2001-2015). BMC Psychiatry. 2017;17(1):342.

21. Thompson PM, Khatun R, llyas M. Women empowerment through financial literacy education. CREL Technical Report; 2018. 
22. INEC. Encuesta Nacional de Relaciones Familiares y Violencia de género contra las mujeres [Internet]. QuitoEcuador: Instituto Nacional de Estadísticas y Censos; 2011 p. 1-49. Disponible en:

https://www.ecuadorencifras.gob.ec/documentos/webinec/Estadisticas_Sociales/sitio_violencia/presentacion.pdf

23. Cunneen C. Conflict, Politics and Crime: Aboriginal Communities and the Police [Internet]. Rochester, NY: Social Science Research Network; 2001 [citado 9 de abril de 2019]. Report No.: ID 2196235. Disponible en: https://papers.ssrn.com/abstract=2196235

24. Koenig MA, Ahmed S, Hossain MB, Mozumder ABMKA. Women's status and domestic violence in rural Bangladesh: Individual- and community-level effects. Demography. 1 de mayo de 2003;40(2):269-88.

25. Bubar R, Thurman PJ. Violence Against Native Women. Soc Justice. 2004;31(4 (98)):70-86.

26. Gómez-Robledo Verduzco A. Caso González y Otras ("Campo Algodonero») vs. México: CIDH, sentencia del 16 de noviembre de 2009. Cuest Const. 2010;(23):245-268.

27. Yépez M. El Femicidio en el COIP [Internet]. Derecho Ecuador. 2014 [citado 17 de julio de 2019]. Disponible en: https://www.derechoecuador.com/el-femicidio-en-el-coip

28. Valle C. Atlas de Género [Internet]. Quito-Ecuador: Instituto Nacional de Estadísticas y Censo (INEC); 2018. Disponible en: https://www.ecuadorencifras.gob.ec/documentos/webinec/Bibliotecas/Libros/Atlas_de_Genero_Final.pdf

29. Cespedes LG, Noles SZ, Espino IC. Violencia contra la mujer y regulación jurídica del femicidio en Ecuador. Dikê Rev Investig En Derecho Criminol Consult Juríd. 2018;(23):129-150.

\section{Figures}

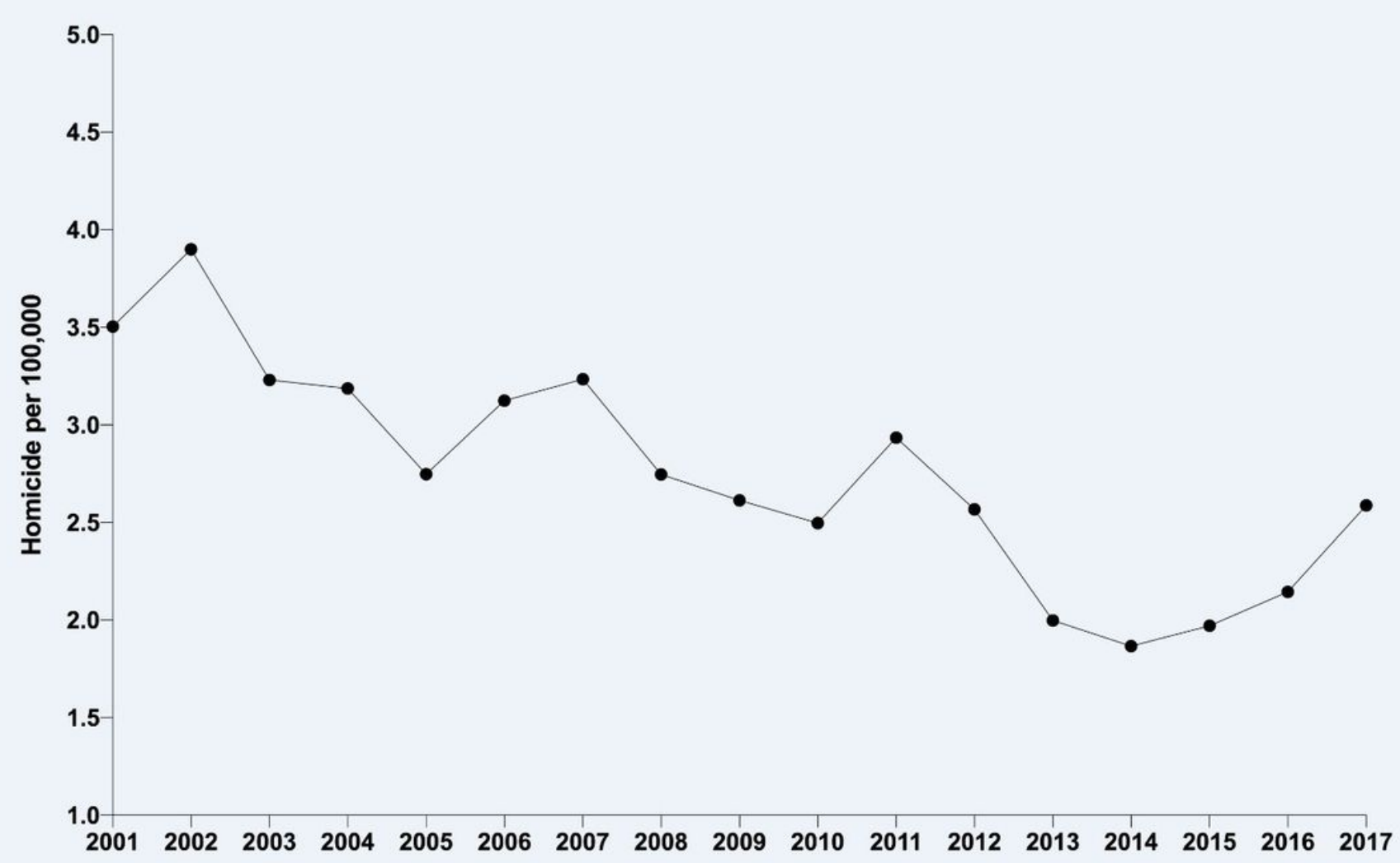


Figure 1

Annual female homicide rate per 100,000 population in Ecuador, 2001 - 2017.

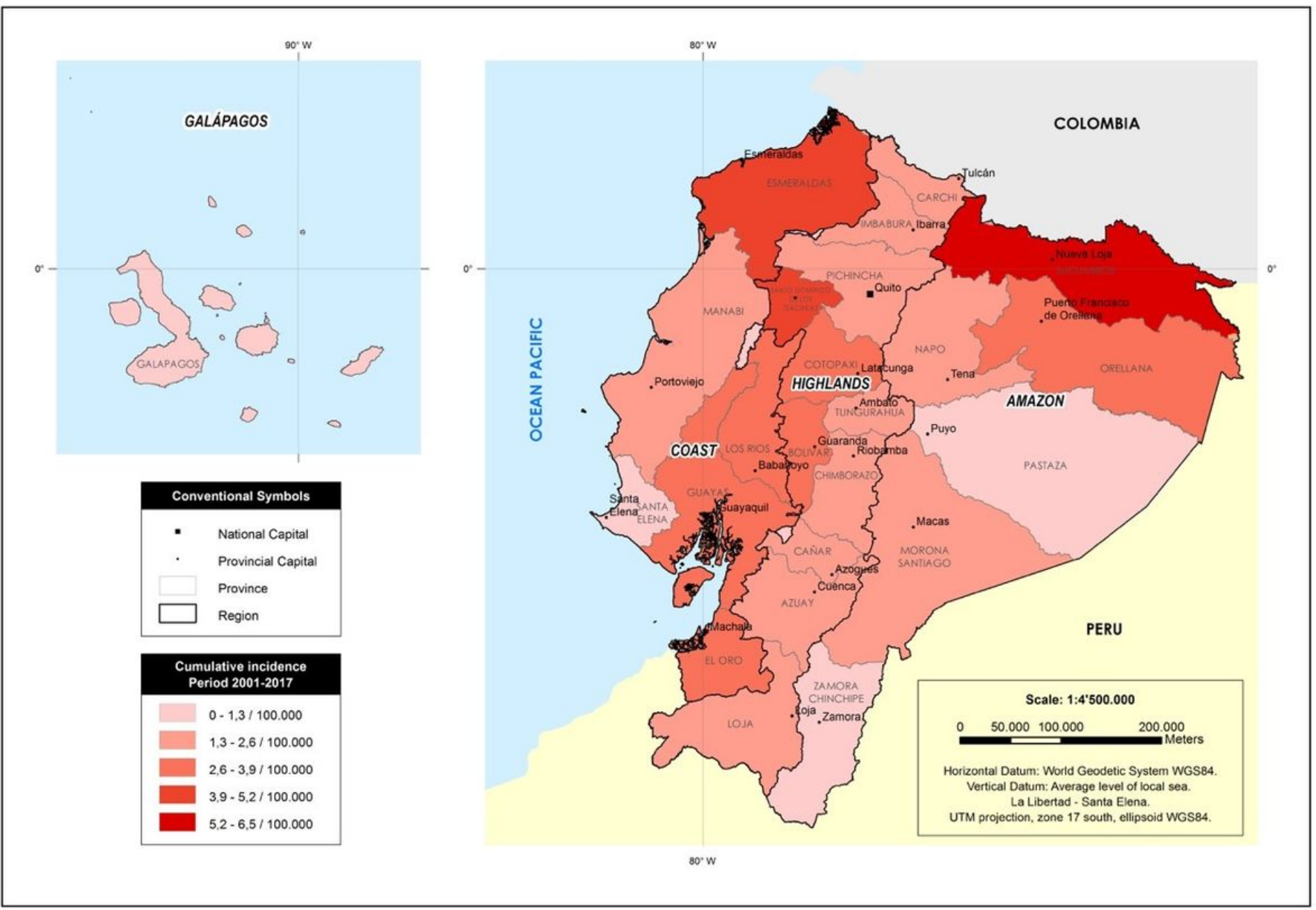

\section{Figure 2}

Cumulative incidence of female homicides by region and province, 2001 - 2017. (The map was created by using ArcGIS. No permissions were required to use this image.) 


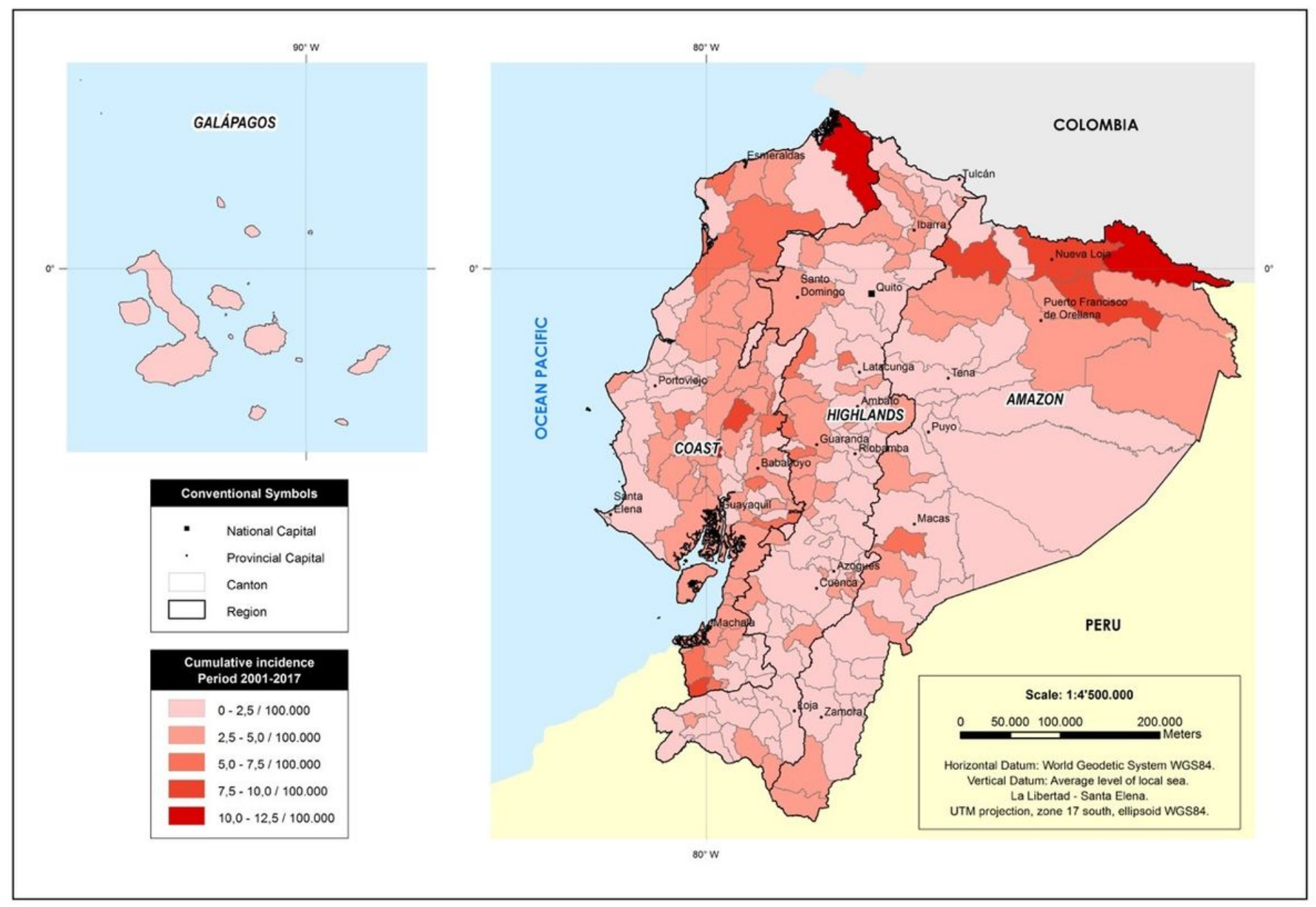

\section{Figure 3}

Cumulative incidence of female homicides by region and canton, 2001 - 2017. (The map was created by using ArcGIS. No permissions were required to use this image.)

\section{Supplementary Files}

This is a list of supplementary files associated with this preprint. Click to download.

- 6Appendix.docx 